WADE, H. E. (1952). J. gen. Microbiol. 7, 18-23

\title{
Observations on the Growth Phases of Escherichia coli, American Type 'B'
}

\author{
By H. E. WADE \\ Microbiological Research Department (Ministry of Supply), Porton, Wiltshire
}

SUMMARY: Observations on the growth phases of Escherichia coli (Bacterium coli), American type 'B', on aerated media are reported. On casein-casein-yeast (CCY) medium the culture passes through the following phases: $(a)$ an initial stationary phase; $(b)$ a logarithmic lag phase; $(c)$ a phase of rapid cell division; $(d)$ a phase of equal division and growth rates; $(e)$ a phase of diminishing growth and division rates. The average cell weight increases regularly through phases $(a)$ and $(b)$ to a maximum. It falls during phase $(c)$ to a lower value at phase $(d)$ and decreases finally to its initial value when the growth rate decreases more slowly than the division rate during phase $(e)$. Similar phases can be recognized during growth on $2 \%$ peptone. The onset of the phase of rapid cell division appears to be stimulated by the concentration of cell material.

It has long been recognized that the growth and multiplication of bacteria can be divided into phases. Those recognized by most workers are the seven proposed by Buchanan (1918), but several anomalies remained until Clarke \& Ruehl (1919) and Henrici (1923) demonstrated the marked changes in cell volume that take place in the course of cultivation, and Hershey $(1938,1939)$ gave a clear distinction between growth, i.e. increase in weight of protoplasm and multiplication, i.e. increase in number of viable units. While investigating fluctuations in the chemical composition of bacteria during their early growth it was necessary to have these growth phases clearly established. The present paper sets out some observations made in an attempt to do this.

\section{METHODS}

A strain of Escherichia coli (Bacterium coli), American type 'B', was used and its growth characteristics were followed during cultivation in aerated CCY medium (Gladstone \& Fildes, 1940) at $37^{\circ}$. Seed cultures were grown in 11 . cylindrical all-glass vessels in which adequate aeration was provided through a sintered glass element at the base. The experimental cultures were grown in 10 l. aspirators and aerated by means of a P 35 'Aerox' element. Air was passed through both cultures at the rate of $2 \mathrm{l} . / \mathrm{min}$./l. medium. Silicone DC Antifoam 'A' (Midland Silicones Ltd.) was used to diminish foaming.

Where practicable the increase in weight of cell material was estimated by direct determination of cell dry weight-otherwise it was estimated indirectly by light absorption. For direct determination volumes of culture sufficient to give 15-30 mg. dry cells were treated with formaldehyde (final concentration $1 \% \mathrm{w} / \mathrm{v}$ ), centrifuged, washed with $0.9 \% \mathrm{w} / \mathrm{v}$ sodium chloride containing $1 \% \mathrm{w} / \mathrm{v}$ formaldehyde and then with $0.05 \%$ sodium chloride and dried at $105^{\circ}$ in small tared tubes. The direct determinations were carried out in triplicate. For indirect determination by light absorption, since no influence 
of cell size on the relationship between turbidity and dry weight could be detected, the light absorption of samples was measured by a Hilger Spekker absorptiometer and the values converted into dry weight cells/unit vol. by means of a calibration curve.

Cell division was followed by nuaking total counts by means of a PetroffHausser counting chamber. The average dry weight/cell was calculated from the dry weights and total count/unit volume. The minimum cell dry weight varied between $3.5 \times 10^{-10}$ and $5 \times 10^{-10} \mathrm{mg}$./cell.

The experiments were conducted in the following way: $10 \mathrm{ml}$. of CCY medium were inoculated with a loopful of a Robertson's broth culture and incubated overnight. This culture served as inoculum for the seed culture of $700 \mathrm{ml}$. CCY medium which was grown in the vessel described above. When no further increase in cell material was observed, the required weight of cells was centrifuged down, washed once in saline and used to inoculate the experimental medium, the growth characteristics of which were to be determined. To avoid loss in viability through storage of the washed seed the seed culture was set up in an electrically heated vaccine bath at room temperature and heat applied by means of a time switch during the night. This ensured that by the following morning the seed .culture had just approached the maximum stationary phase and that the seed prepared from it could be used immediately to inoculate the experimental culture. The average $95 \%$ confidence interval for cell dry weight determination was $\pm 2 \%$; that for the total cell counts was \pm 5 to $8 \%$.

\section{RESUL'TS}

Fig. 1 shows the variation of total cell weight, division rate and average cell weight of a culture inoculated to an initial cell concentration of $c .2 .5 \times 10^{8}$ cells/ ml. and illustrates the first divergence from the conventional growth phases. The initial stationary phase is not followed by a phase of accelerating division (lag phase of Buchanan, 1918) but by a phase of suboptimal logarithmic increase ('logarithmic lag' phase) which results in the average cell dry weight increasing to about three times the initial value at $c .110 \mathrm{~min}$. Subsequent decrease in the rate of formation of cell material relative to the division rate results in a decrease of the average cell weight. Pl. 1 compares cells taken from this culture at $\mathbf{4 0 0} \mathrm{min}$., when no further increase in concentration of cell material could be detected (PI. 1, fig. 1), with cells from the end of the 'logarithmic lag' phase at $110 \mathrm{~min}$. (Pl. 1, fig. 2).

Fig. 2 sets out the results obtained from an experiment when the inoculum was $c .5 \times 10^{7}$ cells $/ \mathrm{ml}$. The 'logarithmic lag' phase was followed by a phase of rapid cell division which exceeded the growth rate and decreased the average cell weight to about twice the minimum. There followed a phase in which division and growth rate were equal, in consequence of which average cell weight remained constant.

Another culture was inoculated to a concentration of $c .10^{6}$ cells $/ \mathrm{ml}$. Fig. 3 shows the changes that took place after the concentration of cell material had reached the lower limit of the absorptiometer, when the degree of turbidity 
could be measured. At $210 \mathrm{~min}$. the average cell weight was $c .4$ times the minimum, and the culture was in the phase of rapid cell division; the phase of equal growth and division rates that followed began at about the same concentration of cell material as in the experiment illustrated in Fig. 2.

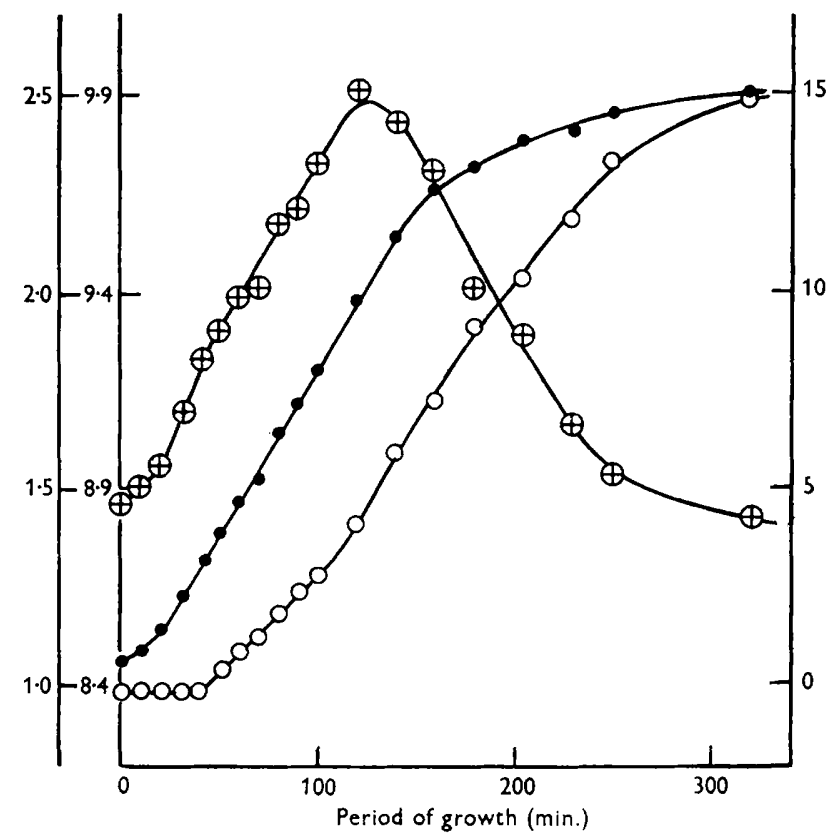

Fig. 1. Growth of Esch. coli on aerated CCY at $37^{\circ}$; inoculum $c .2 .5 \times 10^{8}$ cells $/ \mathrm{ml}$. Ordinates : outer left, log $\mathrm{mg}$. dry weight cells $/ 100 \mathrm{ml}$. medium, - - ; inner, left, log total number cells/ml., $-\mathrm{O}-\mathrm{O}-$; right, average cell weight (mg. $\left.\times 10^{-10}\right),-\oplus-\oplus-$.

These phases, and the changes in growth rate (G.R.), division rate (D.R.) and average cell weight (c.w.) that characterize them (illustrated in Fig. 2) can be summarized as follows:

(a) Stationary phase. G.R. maximal and logarithmic after a short lag; D.R. zero; c.w. increasing.

(b) 'Logarithmic lag' phase. G.R. maximum and logarithmic; D.R. logarithmic, slower than G.R.; C.w. as (a).

(c) Phase of rapid cell division. D.R. as (b); D.R. greater than G.R.; c.w. decreasing.

(d) Phase of equal G.R. and D.R. G.R. as (b); D.R. equal to G.R.; C.W. constant.

(e) Phase of negative growth acceleration. G.R. decreasing; D.R. decreasing more slowly than G.R.; c.w. decreasing to minimum.

Similar phases were recognized during cultivation in $2 \%$ peptone medium. On a defined medium with ammonium lactate base (Cohen \& Anderson, 1946) an inflexion to a faster rate of growth at $c .100 \mathrm{~min}$. was frequently observed. On tryptic meat broth the initial maximum rate of increase in dry weight was of short duration and the growth rate slowly declined, due probably to 
depletion of metabolites necessary for optimum growth. This was suggested by changes in the amount and kind of the ninhydrin-positive components (separated on paper chromatograms) of the medium which were observed during cultivation.

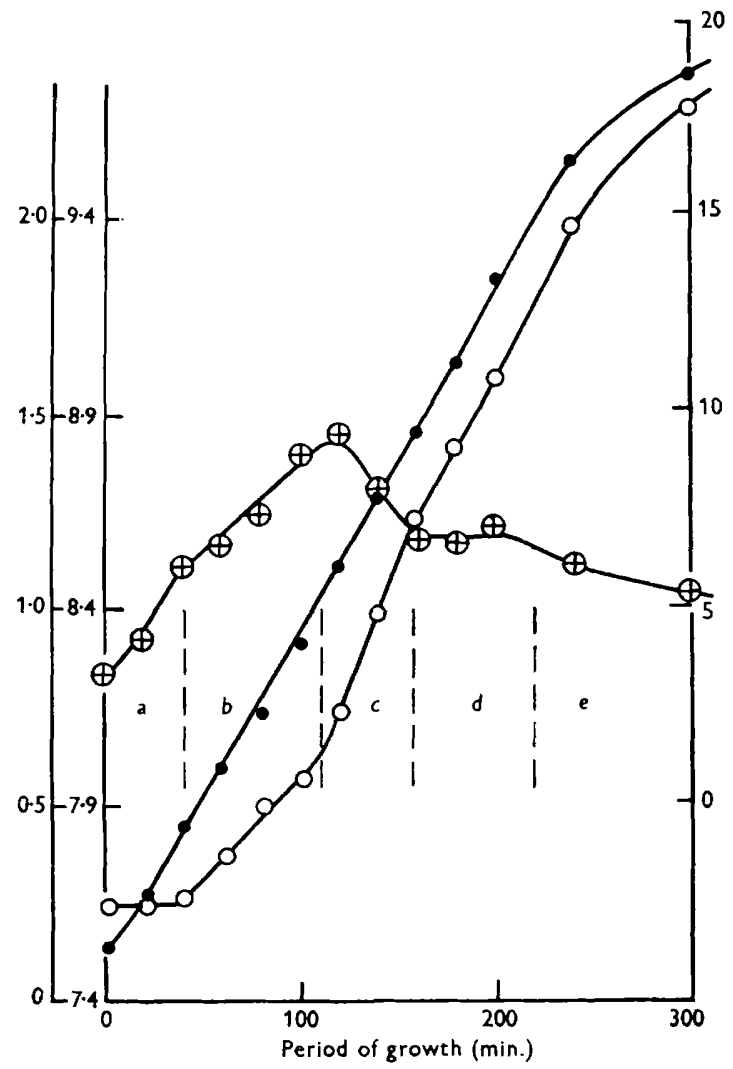

Fig. 2. Growth of Esch. coli on aerated CCY at $37^{\circ}$; inoculum $c .5 \times 10^{7}$ cells $/ \mathrm{ml}$. Ordinates: outer left, log $\mathrm{mg}$. dry weight cells $/ 100 \mathrm{ml}$. medium, number cells/ml., - $-\bigcirc-$; right, average cell weight $\left(\mathrm{mg} . \times 10^{-10}\right),-\oplus-\oplus-$. Letters refer to growth phases described on p. 20 .

In spite of the irregularities that occur on the defined medium and on tryptic meat broth the existence in these cultures of phases similar to those described above was suggested by the changes that occurred in the average cell weight which decreased from the maximum in two stages corresponding with phases $(c)$ and $(e)$ observed in a CCY culture. A further characteristic common to the cultures examined was that the onset of the phase of equal growth and division rates, when present, occurred at $c .30 \mathrm{mg}$. dry weight/100 ml. medium.

\section{DISCUSSION}

The appearance of a 'logarithmic lag' phase was unexpected, and no report of a similar observation could be found in the literature. Examination of the cells towards the end of this phase revealed the presence of few large cells, 
several times the length of the majority (Pl. 1, fig. 2). By assuming that a proportion of the initial population is capable of a decreased regular division rate but of normal regular growth, i.e. increase in total cell mass, the formation of these large cells could account for the presence of this phase. It is likely that the rapid cell division observed is due to division of these large cells, since,

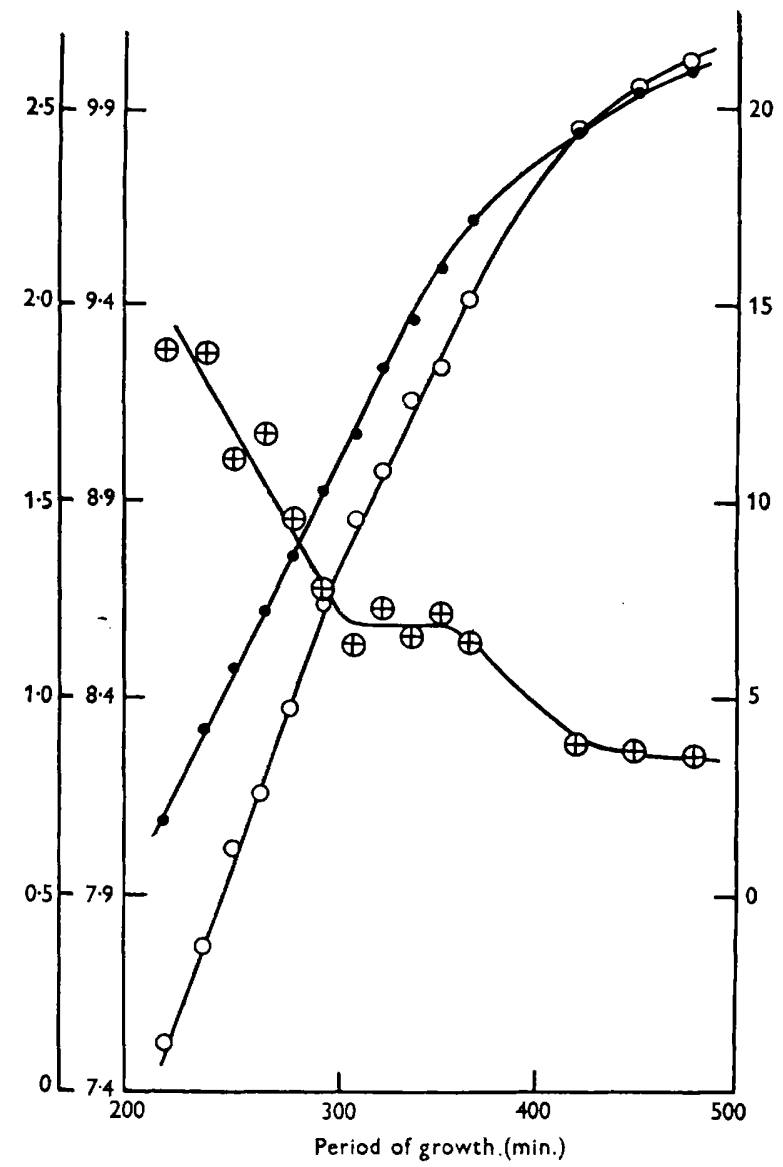

Fig. 3. Growth of Esch. coli on aerated CCY at $37^{\circ}$; inoculum $c .10^{6}$ cells $/ \mathrm{ml}$. Ordinates : outer left, log $\mathrm{mg}$. dry weight cells $/ 100 \mathrm{ml}$. medium, - number cells $/ \mathrm{ml}$., $-\mathrm{O}-\mathrm{O}-$; right, average cell weight $\left(\mathrm{mg} . \times 10^{-10}\right),-\oplus-\oplus-$.

first, the average cell weight decreases to the value expected if all the cells had behaved alike, and, secondly, growth and division rates are equal in the next phase, suggesting that cells are no longer increasing in weight without dividing.

Other workers have reported division rates in excess of growth rates, but the application of the above explanation to their results is questionable. The significance of this phase, however, is naturally bound up with the factors responsible for the diminution in cell volume. It is of interest to recall to what influence other workers have attributed cell volume reduction. Bayne-Jones \& Adolph (1932), who followed growth, division and volume of Esch. coli by 
Journal of General Microbiology, Vol. 7, Nos. $1 \& 2$

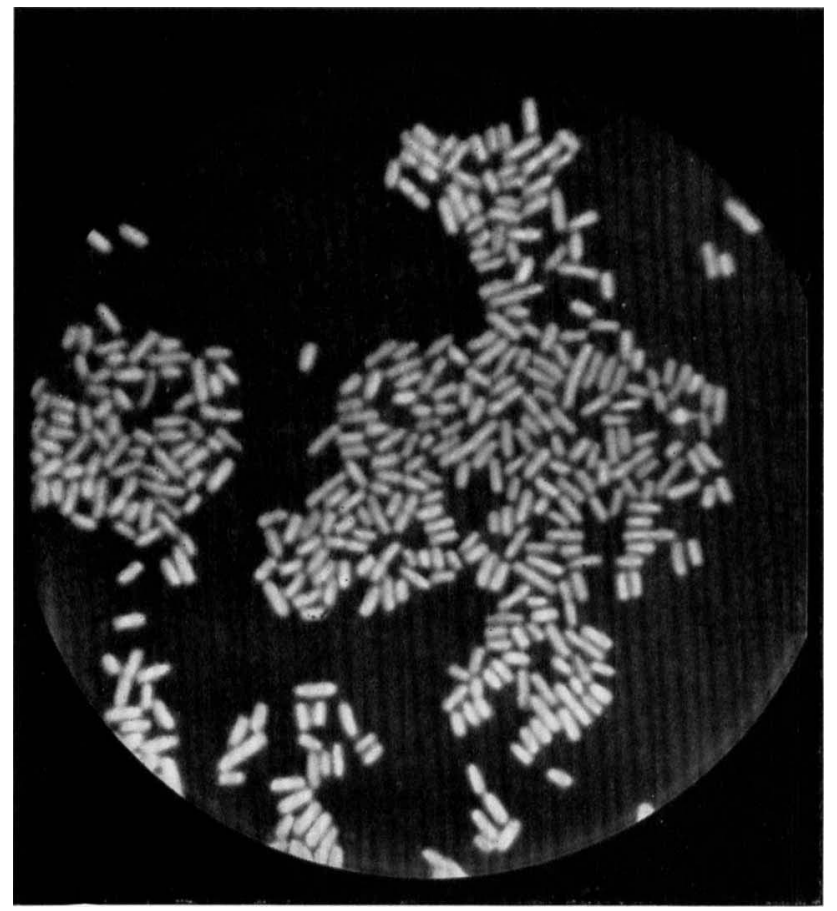

Fig. 1

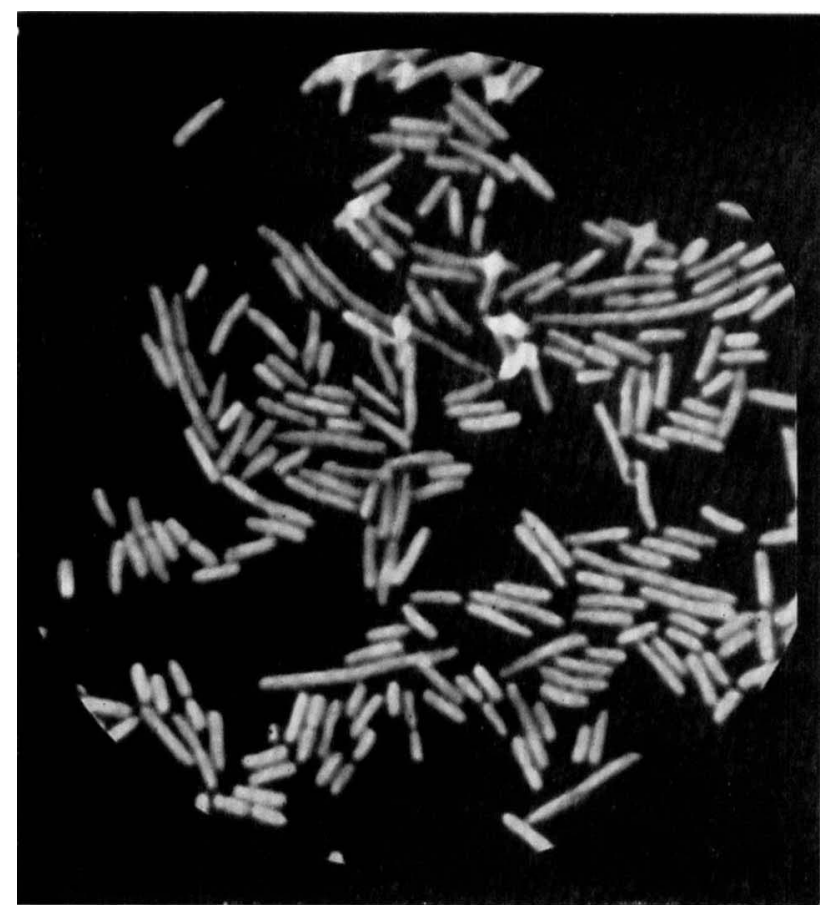

Fig. 2

H. E. Wade-Growth phases of Esch. Coli. Plate 1 